\author{
Leyla ZEYNALOVA, \\ orcid.org/0000-0003-4348-9283 \\ Postgraduate Student at the Department of English Language and Methods \\ Nakhchivan State University \\ (Nakhchivan, Azerbaijan) ismayilovanargis@gmail.com
}

\title{
SEMANTICAL FEATURES OF PHRASEOLOGICAL ANTONYMS IN ENGLISH
}

The study implies criteria for definition, semantic features of antonymic phraseology in English. The major aim of the current article is to identify the phenomenon of antonymy, which occurs as a result of the verbalization of the contradiction between an event, object, sign, and quality in the language. This occurs not only between lexical but also phraseological units of language. In linguistics, both lexical and phraseological antonyms have been studied from various aspects. The article provides a brief overview of research work on phraseological antonyms and their definition, and then discusses the criteria that can be used to determine phraseological antonyms. In phraseological units, antonyms are studied according to the antonymous lexical units included in them. For this purpose, antonymous lexical pairs are taken and phraseological units are selected. Antonyms are sought between these phraseological units, which form two different sets. The analysis shows that the development of antonymous lexical units is not an essential condition for the antinymology of phraseological units. Phraseological antonymy is formed on the basis of contradictions at the level of common meaning. The antonyms of phraseological units include criteria such as semantic contrast in phraseological combinations of the same type of categorical meaning and belonging to the same semantic-grammatical class, similar figurative contrast, lexical antonymy in the component on the basis of structural identity. In this regard, comapative-contrastive methods have been extensively applied as a main reseach methodology and technique in the article. The results of the study indicate that the degree of antonymy in phraseological units compared by semantics can be determined by the number of opposite semantics. However, the main criterion for the antonymy of phraseological units should be the opposite of their general meaning. Consequently, formal indicators of antonyms serve as markers of internal contradiction according to the phraseological meaning, play the role of the semantic center of the phraseological unit. This component determines the completeness of the phraseological meaning.

Key words: antonym, phraseological antonym, structure, image, opposite.

Лейла ЗЕЙНАЛОВА, orcid.org/0000-0003-4348-9283 докторант кафедри англійської мови та методики Нахічеванського державного університету (Нахічевань, Азербайджан) ismayilovanargis@gmail.com

\section{СЕМАНТИЧНІ ОСОБЛИВОСТІ ФРАЗЕОЛОГІЧНИХ АНТОНІМІВ АНГЛІЙСЬКОЮ МОВОЮ}

Дослідження передбачає критерії визначення, смислові особливості антонімічної фразеологї. Основна мета даної статті - виявити феномен антонімії, який виникає в результаті вербалізачії протиріччя між подією, предметом, знаком і якістю в мові. Це відбувається не тільки між лексичними, а й фразеологічними одиницями мови. У лінгвістиці лексичні та фразеологічні антоніми вивчаються з різних боків. У статті надано короткий огляд дослідницької роботи щзодо фразеологічних антонімів і їхніх визначень, а потім обговорюються критерії, які можуть бути використані для визначення фразеологічних антонімів. У фразеологізмах антоніми вивчаються по вхідних у них антонімічних лексичних одиницях. Для иььго беруться лексичні пари і виділяються фразеологізми. Антоніми шукають між циии фразеологізмами, які утворюють два різних набори. Аналіз показує, щео розвиток антонімічних лексичних одиниць не є обов'язковою умовою антонімології фразеологізмів. Фразеологічна антонімія формується на основі протиріч на рівні буденного значення. До антонімів фразеологізмів відносяться такі критерії, як семантичний контраст у фразеологічних сполученнях одного типу категоріального значення та приналежність до одного семантико-граматичному класу, схоже образне протиставлення, лексична антонімія в компоненті на основі структурної ідентичності. У зв'язку з цим порівняльно-контрастні методи широко застосовувалися як основна методологія $i$ техніка дослідження. Результати дослідження показують, щзо ступінь антонімії порівнюваних по семантиці фразеологізмів можна визначити за кількістю протилежних семантик. Однак головним критерієм антонімії фразеологізмів повинна бути протилежність їхнього загального значення. Отже, формальні індикатори антонімів служать маркерами внутрішнього протиріччя по фразеологічним значенням, відіграють роль смислового центру фразеологізму. Цей компонент визначає повноту фразеологічного значення.

Ключові слова: антонім, фразеологічний антонім, структура, образ, протилежність. 
Introduction. Semantical features of phraseological antonyms in English is one of the main and interesting part of English grammer. Of course till our days this field of the grammer haven 't been learnt enough, but there is some researches about it. For us learning of semantical features of phraseological antonyms in English is more important. And someone may be asked why? As it yes in English in all languages phraseological units, their forms, its antonymy, especially semantical features of phraseological antonyms is more interesting and also difficult. And we think that investigations on this field will be help to each learner or researcher to understand the meaning of phraseological antonyms. From this piont of view we hope that this article will have a great number of importance in understanding of the semantical features of phraseological antonyms in English. The article implies antonymic relationships in phraseology on the basis of phraseological nominative units. The main goal of the research is to identify and reveal the degree of antonymy in phraseological units or set phrases by comparing the antonymous words. One of the main aims of article is to assertain the essence of antonymy which is a contradiction based on the opposite of the meaning of nominative units. Although antonymy is widely expressed in lexical units, this phenomenon is also recorded in phraseology. The antonyms of phraseologies differ from lexical antonyms. In this regard, it is necessary to define the criteria for determining phraseological antonyms, to classify phraseological antonyms, and then to study their semantic features. The study of the definition and clarification of the conditions for the formation of antonyms between two phraseological units, the identification and systematization of formal signs of antonyms in pairs is distinguished by the relevance of materials based on materials of different languages, including English. Such research will provide important material for analysis of comparative and contrastive research. In addition, it is of great significance to reveal and systematize the semantic features of phraseological antonyms, to compare the results with current research.

Description of the research materials and methods. The so-called section of the study considers the overview of the development of the problem of phraseological antonyms. The issue of phraseological antonymy has been addressed by various researchers, and this problem has been studied on the basis of phraseological units of different languages, including English. An analysis for the current reference shows that researchers refer more to the work by A. V. Kunin and E. N. Miller on this issue. According to Kunin the phraseologisms with a common semantic component in the presence of polar meaning are antonym-related units (Kunin, 1996). A number of studies have been conducted on the phraseological antonyms of the English language, in which the issues of antonymy in general and antonymic issues in phraseological units have been studied. And during our investigations we see that one of the best classification forms of phraseological antonyms was given in detail in Miller's researches (Miller, 1990).

In research "Antonyms in English. Construals, Constructions and Canonicity" carried out by Jones S., Murphy M. Lynne, Paradis C., Willners C. suggests that the study of antonyms helps to obtain important information about the meaning of words and phrases and the structure of discourse.

Research related to the essence of antonymy, definition and their classification as well as the criteria for determining the antonymic relationships between phraseological units.

Determinative criteria for phraseological antonyms are of special importance in the process of compiling a dictionary of phraseological antonyms. But a pity there is no dictionary of phraseological antonyms in English yet. One of the most striking features of research on phraseological antonyms is that the authors pay attention to the external side of phraseological units, or rather, to the lexical units within them. However, it should be taken into account that figurativeness is one of the main features in phraseology.

The analysis of phraseological units from the cognitive aspect increased the attention to their figurativeness and gave impetus to the study of the role of this factor in the definition of phraseological antonyms. The role of contractual figurativeness in the formation of opposite meanings in the phraseological unit was studied. The author considers the possibility of applying cognitive linguistic methods to the study of phraseological antonyms (Skvortsova, 2018).

Research on phraseological antonyms shows that the criteria for distinguishing antonyms vary depending on the approach to the problem. In all cases, the main important condition for phraseological antonymy can be considered the analysis of the internal organizers of phraseology.

The classification of phraseological antonyms has always been in the focus of researchers. Based on lexical-grammatical characteristics, four types of phraseological antonyms were distinguished: 1) verb; 2) noun; 3) adjective; 4) adverbial (Arnold, 2012: 22).

In A. V. Kunin's researches we see that the investigator distinguished five semantic types of phraseological antonyms in modern English.

The principles of determining the antonymic relations between phraseological units are impor- 
tant for the construction of phraseological antonymic pairs. The analysis shows that a number of antonymic phrasal pairs are given in the works of researchers who have conducted research in this area. This aspect helps to collect and record antonymous phraseologies.

There are some principles of determining the antonymic relationship between phraseological units. The principles of defining antonyms in phraseology are to some extent similar to the principles used in lexicology. The definition of antonymic relationships is based on three main criteria: 1) semantic; 2) syntactic; 3) functional (Poddyachaya, 2009).

The following antonymic principles are revealed in the research conducted on the basis of semantic criteria: 1) the existence of mutually exclusive opposite semantics; 2) belonging of phraseological antonyms to the same category of meaning type and belonging to the same semantic-grammatical class; 3) determination of phraseological antonymy on the basis of figurative component.

The first sign, or more precisely, the existence of contrasting semantics that are mutually exclusive, is debated in antonymous phraseologies as to whether such semantics are the same number. Of course, it is more logical to have the same amount of compared sems. However, it should be noted that polysemy is observed in some phraseologies. In such cases, if the opposite is confirmed by one sem line, the antonym does not appear in the direction of the other meaning. As a result, the antonymy of phraseological units are recorded on the basis of a single meaning.

The degree of antonymy in phraseological units compared by semantics can be determined by the number of opposite semantics. However, the main criterion for the antonymy of phraseological units should be the opposite of their general meaning.

The antonymy of the two phraseological units can also be checked on the basis of the antonymous words in them. In English, the lexical units «dark» and «light» are antonyms. There are phraseologies in English that contain these lexemes. For example, phraseologisms containing the word "dark", "be in the dark", phraseologisms containing the word "light", "by the light of nature" and etc.

In order to study antonyms in English phraseology, it is more expedient to create thematic groups on opposites based on conceptual features that are more pronounced in reality, and to analyze the phraseologies included in these groups. Let's try to build thematic groups based on such conceptual features. If we construct the opposite conceptual sign in the form of "good object - bad object" or "successful object unsuccessful object", we will have identified antonym pairs that represent the realization of the meaning of whether the final result is either obtained or not.

The phraseology "A jewel in someone's crown" is used to mean "someone's best possession or achievement". The antonym of this unit is "to run into the ground». The latter means that a job, an activity, fails. Formal indicators of antonyms serve as markers of internal contradiction according to the phraseological meaning, play the role of the semantic center of the phraseological unit. This component determines the completeness of the phraseological meaning.

In general, the analysis of the lexical-semantic composition of phraseological antonyms allows to distinguish the following types of antonyms: 1) antonyms with the formally motivated opposite meaning; such phraseologies do not contain common and antonymous components. For example, "beyond praise" (very good; praiseworthy) and "in a tin pot way" (very bad, useless); 2) phraseological antonyms containing lexical antonyms. For example, "in hot blood" and "in cola blood"; 3) those that contain an antonym-forming component in one of the phraseologies that form a pair of antonyms. For example, "the acceptable face of" and "the unacceptable face of". A comparison of the antonym pairs discussed above reveals that they differ in structure.

It should be noted that phraseological antonyms, which express the absolute consonant opposite, are also divided into two parts. The first constant is called opposite antonyms. Such pairs of antonyms are called denotations, which have a constant opposite relationship to each other. For example, oranges sour (weather that does not allow to fly) - oranges suret (weather that allows to fly). The second type is called dynamic opposite antonyms. In such an antonym, the degree of opposition is the change and the opposite direction of the denotations. For example, "to come down" - "to go up".

In antonyms that express relative opposite, the contradiction is expressed to some extent. For example, golden parachute - tin parachute. Golden parachute is high sum of money (a kind of indemnity) given to the collaborator who is dismissed from work while low parachute means low sum of money given to the dismissed employee.

The criterion of semantic membership and autonomy of separate components of phraseology allows to compare those components in reverse. The existence of strong formal similarities between phraseologies is accepted as another condition of the antonymic relationship. In the case of strong formal similarity, the internal form of the compared units overlaps with as much accuracy as negation or up to one element. Non-overlapping elements are lexical or contextual antonyms. 
If we take a subject instead of "object in the conceptual sign chosen above to form a thematic group, we will have adopted the second conceptual sign. In this case, there is a comparison of "successful subject - unsuccessful subject".

Phraseologisms such as "king of the castle / hill", "to have the world at your feet», «fortune smiles on somebody" will express a successful subject to this thematic group. Dozens of phraseological units that can form pairs of antonyms include: "a born loser", "to fall flat on your face", "close but no cigar" and so on.

It should also be noted that the concepts of object and subject in conceptual features are not antonyms with each other. These words are used to name a thematic group.

If we literally translate the phraseology "To have the world at your feet" into Azerbaijani, it means "to feel the world under your feet". There is a phraseological unit in the Azerbaijani language "to be on the seventh floor of the sky", which has the same meaning as the phraseology in English, or can be considered as the equivalent of the English phraseology. Both units represent a successful subject.

In English, the phraseology "to close but no cigar" as an antonym variant or the phraseological unit "to fall flat on your face" serves as the second side of the antonym pair. In the Azerbaijani language, the expression "to be black-faced" does not form an antonym with the phraseology "to be on the seventh floor of heaven". However, this unit can be used interchangeably with "to fall flat on your face". This shows that the antonym pairs of phraseological units do not indicate the similarity of each other in different languages.

The fact that phraseological units belong to the same part of speech is considered to be one of the semantic features of their antonymy. Antonyms are more productive when they refer to the same parts of speech. Herewith, it is possible that the semantic contrast finds expression in different lexicalgrammatical classes of words. Such antonyms are revealed in connection with the categorical meaning of language units.

Y. N. Miller shows that since antonyms are a category of content plan, it is possible to contrast any nominative units with opposite meanings. In this case, the difference in the expression plan is not significant (Miller, 1990). The opposition of different speech feelings is due to the fact that the same events of reality are called by different parts of speech. In this case, despite the diversity of categorical-grammatical semantics, if they have a categorical-lexical sem of the same name, it is also possible to contrast them. (Solovyova, 2017: 17).
The formation and functioning of phraseological units are a complex process. In this process, language speakers perceive and master certain images in practice. Therefore, figurativeness is a characteristic feature of the phraseological unit. A phrase is based on the opposite image in phraseological antonyms. For example, to play one's cards well - to play one's cards badly phraseological antonymic pair is based on figurativeness. It is true that this pair of antonyms also has a well-badly lexical antonymy. However, it is not a good or bad comparison of phraseological units in general sense, but it is important to do the job skillfully or incompetently.

We have shown on the basis of "dark" and "light" units that the inclusion of lexical antonyms in the structure of the compared phraseological units does not always reveal the antonymy of phraseological units. However, the presence of a lexical antonymy in the composition sometimes acts as a sign of phraseological antonymy. Based on the syntactical criterion, if there is a component in the same structural phraseological units and these components are a pair of lexical antonyms, then the phraseology also forms an antonymous pair. For example, "to come to the right shop" and "to come to the wrong shop". These phraseologies consist of the same number of components. They differ in the lexical unit they contain, and these lexemes are antonyms: right - wrong.

Results and discussions. Phraseological units with similar lexical combinations and the same structure form a pair of phraseological antonyms when they have opposite meanings.

Thus, the main antonymous signs of phraseological units include the following: 1) the opposite of meaning in phraseological combinations of the same type of categorical meaning and belonging to the same semantic-grammatical class; 2) similar image-based contrast; 3) Lexical antonymy in phraseologies with the same structure and similar components; 4) similar lexical combination of structure and semantic contrast; 5) belonging of the compared phraseologies to the same functional style.

While researching the study, it is essential to mention semantic aspects of phraseological expressions expressing antonymic attitude. In modern English, it is possible to divide antonymous phraseological units into different semantic types. Such a distinction expands the possibilities of expression of the field of contrasting semantic content expressed by antonymous lexical units. If "good-bad" is a pair of antonyms, it means a certain opposite in sign or quality. There are other ways in which language can express this contrast, or more precisely, the "good-bad" opposition. There are phraseological antonyms that also 
mean "good - bad". For example: come to the right shop - to apply to the right person; go where you need to go; come to the wrong shop - come to the wrong address; go where you don't need to go; earn an honest penny - live by one's wits - earn by any means, fair play - just play; honesty, truthfulness; foul play ugly game, low action; good form - good behavior bad form - bad behavior; in good faith - in an honest manner - in bad faith - in a dishonest manner; be in smb.'s good books - to be good in someone's eyes; be in smb.'s bad books; play one's cards well - to do work properly, play one's cards badly - to do work improperly; swim like a duck (fish) - swim like a stone $=$ swim like a stone; with a good grace - with gratitude, enthusiasm; - with a bad grace - reluctant, impassionate, etc.

Conclusion. Result we must note that phraseological antonymy is of particular interest in terms of identifying the causes of it, revealing the criteria for determining the pairs of phraseological antonyms. Defining and comparing phraseological antonyms in different languages, the common system of features for phraseological antonyms is more difficult, but the same time is more interesting. The research shows that the main features for phraseological antonymy can be attributed to the presence of the same semantic structure of the phraseology compared to the phraseology, the similarity of the lexical-semantic and syntactic combination.

In the article we tried to give the comparative investigation of the semantical features of phraseological antonyms in English with other world languages. And the researches showed that they are differ from one another in each languages. For us it is impossible to learn the semantical features of phraseological antonyms in English in one article. To our mind still the studies on this field need to continue and develope.

\section{BIBLIOGRAPHY}

1. Arnold I. V. Lexicology of modern English. Moscow : FLINT, 2012, 376 p.

2. Antonyms in English. Construals, Constructions and Canonicity / S. Jones et al. Cambridge University Press, 2012. $263 \mathrm{p}$.

3. Kunin A. V. Phrapzeology of modern English. Moscow : Higher School, 1996. 380 p.

4. Miller Y. N. The nature of lexical and phraseological antonymy. Saratov : Publishing House of the SU, 1990. 222 p.

5. Поддячая И. А. Парадигматические отношения фразеологических единиц качественно-обстоятельственного класса в русском и английском языках : дисс. ... канд. филол. наук. Челябинск, 2009. 276 с.

6. Скворцова Н. С. Опыт изучения антономических отношений во фрвзеологии сквозь призму когнитивной лингвистики. Вестник МГЛУ. Гуманитарные науки. Москва, 2018. Вып. 13 (807). С. 259-270.

7. Соловьева Н. В. Языковая и речевая оппозитивность в тексте народной сказки. Н. В. Соловьева. Вестник Московского государственного областного университета. Серия: Лингвистика. 2017. № 2. С. $12-22$.

\section{REFERENCES}

1. Arnold I. V. Lexicology of modern English. -Moscow, FLINT, 2012, 376 p.

2. Jones S., Murphy M., Lynne, Paradis C., Willners C. Antonyms in English. Construals, Constructions and Canonicity. Cambridge University Press, 2012, 263 p.

3. Kunin A. V. Phrapzeology of modern English. Moscow, Higher School, 1996, 380 p.

4. Miller Y.N. The nature of lexical and phraseological antonymy. Saratov, Publishing House of the SU, 1990, $222 \mathrm{p}$.

5. Poddjachaja I.A. Paradigmaticheskie otnoshenija frazeologicheskih edinic kachestvenno-obstojatel'stvennogo klassa $\mathrm{v}$ russkom i anglijskom jazykah: [Paradigmatic relations of phraseological units of a qualitative-adverbial class in Russian and English] Chelyabinsk, 2009, 276 s. [in Russian]

6. Skvorcova N.S. Opyt izuchenija antonomicheskih otnoshenij vo frvzeologii skvoz' prizmu kognitivnoj lingvistiki. [Experience of studying antonomical relations in frvzeology through the prism of cognitive linguistics] Vestnik MGLU. Humanitarian sciences. Issue 13 (807), Moscow, 2018, pp. 259-270 [in Russian]

7. Colov'eva N. V. Jazykovaja i rechevaja oppozitivnost' v tekste narodnoj skazki [Language and speech opposition in the text of a folk tale] Bulletin of the Moscow State Regional University. Series: Linguistics, 2017, No. 2. pp. 12-22 [in Russian] 